\title{
Acid soil amendment by zeolite, sepiolite and diatomite
}

\author{
Chompoonut Chaiyaraksa*, Mintra Tumtong \\ Faculty of Science, King Mongkut's Institute of Technology Ladkrabang, Bangkok 10520 Thailand
}

*Corresponding author, e-mail: kcchompoonut@gmail.com

Received 16 Apr 2019

Accepted 30 Jun 2019

\begin{abstract}
The aim of this research was to reduce the heavy metal movement to the biosystem using clay minerals including zeolite, sepiolite, and diatomite. The clay soil and sandy loam soil were made contaminated with 200, 350, 700 , and $250 \mathrm{mg}$ of $\mathrm{Zn}, \mathrm{Cu}, \mathrm{Cr}$, and $\mathrm{Ni}$ per $\mathrm{kg}$ of soil, respectively. The ratio of clay minerals added to soils was $2.5 \%$, $5 \%$, and $7.5 \%$. The determination of various forms of heavy metals bound to soil mixed with clay minerals and left for a period of 30 and 60 days was carried out using the sequential extraction method. The results indicated that $\mathrm{Ni}$ and $\mathrm{Zn}$ were mostly in an exchangeable form, while $\mathrm{Cu}$ and $\mathrm{Cr}$ were mostly in an oxide bound form and an organically bound form. The $\mathrm{pH}$ of the soils increased after adding clay minerals. Diatomite caused the smallest change in the $\mathrm{pH}$ value. Chromium had the best adsorption capacity by bonding with various elements in the soil, followed by Cu, $\mathrm{Zn}$, and Ni, respectively. The addition of sepiolite caused more heavy metals in a stable form than adding zeolite and diatomite. When adding clay minerals to both types of soil, the highest impact was on $\mathrm{Ni}$, followed by $\mathrm{Zn}, \mathrm{Cu}$, and $\mathrm{Cr}$, respectively. The bioavailable index (BI) value was the least when adding sepiolite. The risk of heavy metals moving to the biosystem was lower when increasing the incubation time. Without adding any clay mineral, the BI value of metals in the sandy clay loam soil was higher than that in the clay soil.
\end{abstract}

KEYWORDS: diatomite, heavy metals, sepiolite, soil, zeolite

\section{INTRODUCTION}

The development of technology and industrial expansion results in environmental problems. Soil pollution is one of these problems. Various industrial plants use chemicals such as heavy metals, which are then released as waste to the soil ${ }^{1}$. Referring to Agency for Toxic Substances and Disease Registry (ATSDR), zinc, copper, chromium, and nickel are classified as dangerous heavy metal no. 74, 128, 18 , and 27 , respectively. Zinc is used as a coating to prevent the corrosion of electrical equipment, while copper is used in the production of electrical wires. Chromium is used in the plating industry, tanning, etc., and nickel is used in the stainless steel and alloy steel industry ${ }^{2}$. The problem of the contamination of heavy metals in the soil affects humans throughout the food chain. Plants that grow in areas contaminated with heavy metals will absorb toxic substances. When humans and animals consume toxic substances, the substances will enter the body ${ }^{3}$. Reducing the transmission of heavy metals from the soil to plants can be accomplished by adding an immobilizing agent ${ }^{4}$. The materials used to act as immobilizing agents include phosphate compounds ${ }^{5}$, alkaline compounds and clay minerals, etc. ${ }^{6,7}$. Ling et $\mathrm{al}^{8}$ studied the efficacy of sepiolite and palygorskite in improving cadmium contamination areas. They cultivated two species of rice, namely Zhonglianyou 950 (ZLY-950) and Fengyou 9 (FY-9), and examined the accumulation of cadmium in these rice species. Sepiolite and palygorskite increased soil $\mathrm{pH}$. FY-9 rice varieties grown in sepiolite-modified soils had a concentration of cadmium in the range of $0.181-0.345 \mathrm{mg} / \mathrm{kg}$. That range was acceptable in the Codex standard food. Sun et $\mathrm{al}^{7}$ studied the efficacy of bentonite in improving farmland contaminated with cadmium and lead. They studied heavy metal adsorption of rice, metal fractions in the soil, and enzyme activity. The results of the improvement showed that bentonite increased the activity of superoxide dismutase in the root, peroxidase in the leaves, and soluble protein in the roots. There were changes from the parts that the plant could use (available form) to the parts the plant could not use (non-available form). Bentonite could inhibit the movement of cadmium and lead from the soil to the aerial part. Li et al ${ }^{9}$ synthesized lead-contaminated soil $(0,125,500,1000$, and $2000 \mathrm{mg}$ per kilogram) and determined the soil regeneration efficiency by zeolite (added zeolite 0, 5,10 , and 20 grams per kilogram of soil). They studied the adsorption of heavy metals in white 
stalks. The results of soil improvement revealed that zeolite increased $\mathrm{pH}$, cation exchange capacity and organic matter in the soil. They also found that the optimal zeolite content was 10 grams when lead metal was at concentrations greater than 1000 mg per kilogram of soil. Zeolite could inhibit lead adsorption of white stalked cabbage by reducing the lead concentration in the edible part of the plant by up to $30 \%$. Ye et al ${ }^{10}$ studied the effectiveness of diatomite in reducing lead, copper, and cadmium movement by making soil amendment at the ratios of $2.5 \%$ and $5 \%$. After mixing for 90 days, the efficiency was tested by extraction with $0.01 \mathrm{M}$ $\mathrm{CaCl}_{2}$. They found that diatomite was effective in reducing the movement of heavy metals in the soil. With a ratio of $5 \%$ diatomite, the reduction of movement for lead, copper, and cadmium was $43.5 \%$, $26.3 \%$, and $12.7 \%$. Urease, acid phosphatase, and dehydrogenase changed in a positive way compared to the soil without improvement. Zhang et $\mathrm{al}^{11}$ reported the restoration of copper contaminated soil with attapulgite and montmorillonite. The highest copper absorption value of attapulgite and montmorillonite was $1501 \mathrm{mg}$ and $3741 \mathrm{mg}$ per kg, respectively. Montmorillonite had better potential to reduce copper than attapulgite. Zhang and $\mathrm{Pu}^{12}$ reported the ability to retain heavy metals in four soil amendments, namely agricultural limestone, rock phosphate, palygorskite, and calcium magnesium phosphate. Additives were mixed at a ratio of $2 \%$ and $5 \%$ into the calcareous soil and acidic soil contaminated with lead, cadmium, copper, and zinc. Palygorskite and calcium magnesium phosphate were more effective in fixing heavy metals in the form of bioavailability than agricultural limestone and rock phosphate. Venegas et $\mathrm{al}^{13}$ studied the acid neutralization capacity and ability to absorb lead, zinc, cadmium, nickel, and chromium of compost from municipal solid waste (MSW), domestic organic matter (DOM), compost from green solid waste (GW), husk waste from olive $(\mathrm{OWH})$, olive peel (OP), biochar from fruit (BF), and biochar from the grape stem (BS). MSW and GW showed the highest acid-neutral capability. GW, BF, MSW, and BS were suitable materials for environmental restoration since they could increase soil $\mathrm{pH}$ and the ability to absorb heavy metals. The aim of this research was to study the reduction of heavy metals ( $\mathrm{Zn}, \mathrm{Cu}, \mathrm{Cr}, \mathrm{Ni}$ ) movement to the biosystem using clay minerals (zeolite, sepiolite, and diatomite). The forms of heavy metals in the soil after different incubation time were also determined.

\section{MATERIALS AND METHODS}

\section{Soil sample}

Clay soil sample (C) from Mon Thong sub-district, Bang Nam Priao district, Chachoengsao province $\left(13^{\circ} 51^{\prime} 49.687^{\prime \prime} \mathrm{N}, 100^{\circ} 59^{\prime} 20.548^{\prime \prime} \mathrm{E}\right)$ and sandy clay loam soil samples (S) from Plaeng Yao subdistrict, Plaeng Yao district, Chachoengsao province $\left(13^{\circ} 35^{\prime} 42.104^{\prime \prime} \mathrm{N}, 100^{\circ} 15^{\prime} 46.681^{\prime \prime} \mathrm{E}\right)$ were collected at the depth of $0-30 \mathrm{~cm}$. Samples were crushed, dried, sieved through a $2 \mathrm{~mm}$ sieve, and stored in a plastic container. The metalcontaminated soils were prepared by adding 200 , 350, 700, and $250 \mathrm{mg}$ of zinc, copper, chromium and nickel per kilogram of soil, respectively.

\section{Analysis of basic properties of soil}

The $\mathrm{pH}$ (pH meter, Consort C860), moisture (drying in an oven at $110^{\circ} \mathrm{C}$ and calculating the mass loss), particle distribution (Hydrometer ASTM No. $1.152 \mathrm{H}$ ), organic matter (Walkley black titration method), cation exchange capacity (Ammonium saturation method), total $\mathrm{N}$ (Kjeldahl method), available P (Bray (II) method), and available K (Atomic absorption spectrophotometer, AAS) were determined using the method developed by the Department of Land Development ${ }^{14}$. The determination of total metals was by Atomic absorption spectrometer (AAS, Analyst 200, Perkin Elmer) (EPA 3050B method) ${ }^{15}$.

\section{Analysis of basic properties of clay minerals}

The moisture (drying at $110^{\circ} \mathrm{C}$ and calculating the mass loss), and cation exchange capacity (Ammonium saturation method) were determined using the method developed by the Department of Land Development ${ }^{14}$. The determination of total metals was by AAS (Analyst 200, Perkin Elmer) ${ }^{15}$. The analysis of the total surface area, porosity volume, and porosity size were by Brunauer Emmett Teller (BET)/Gas Adsorption Analyser. The observation of the elemental composition of materials was by Xray fluorescence (XRF) (SRS 3400, Siemens). The examination of the point of zero charges (pHpzc) was by a salt addition method ${ }^{16-18}$.

\section{Efficiency of clay minerals}

The soil was mixed with clay minerals (zeolite, sepiolite, diatomite) at the ratio of $0 \%$ (control), $2.5 \%, 5 \%$, and $7.5 \%(\mathrm{w} / \mathrm{w})$ and left for 30 and 60 days. Maintaining the field moisture capacity (clay $32 \%$, sandy clay loam 24\%) during the mixing period was by using deionized water. The metals 
Table 1 Characteristics of types of soil.

\begin{tabular}{lcc}
\hline Parameter & $\mathrm{C}$ & $\mathrm{S}$ \\
\hline $\mathrm{pH}$ & $4.41 \pm 0.07$ & $4.80 \pm 0.08$ \\
Moisture (\%) & $37.82 \pm 1.10$ & $6.20 \pm 0.32$ \\
Soil distribution & & \\
$\quad$ \% sand & $59.83 \pm 2.71$ & $29.47 \pm 3.62$ \\
$\quad$ \% silt & $22.69 \pm 2.93$ & $51.05 \pm 4.36$ \\
$\quad$ \% clay & $17.48 \pm 1.14$ & $19.48 \pm 1.54$ \\
Type of soil & Clay & Sandy clay loam \\
Organic matter (\%) & $2.63 \pm 0.14$ & $2.21 \pm 0.11$ \\
CEC (cmol $/ \mathrm{kg})$ & $21.15 \pm 1.56$ & $5.97 \pm 0.23$ \\
Total N (\%) & $0.004 \pm 0.003$ & $0.005 \pm 0.004$ \\
Available P (mg/kg) & $2.90 \pm 0.51$ & $3.18 \pm 0.15$ \\
Available K (mg/kg) & $36.70 \pm 1.39$ & $29.54 \pm 2.63$ \\
Zn (mg/kg) & $58.05 \pm 5.83$ & $20.20 \pm 1.35$ \\
Cu (mg/kg) & $21.53 \pm 0.76$ & $12.24 \pm 0.16$ \\
Cr (mg/kg) & $45.44 \pm 4.58$ & $12.77 \pm 0.52$ \\
Ni (mg/kg) & $41.30 \pm 3.34$ & $15.88 \pm 1.05$ \\
\hline
\end{tabular}

in soil sample were extracted and separated into 6 fractions by sequential extraction method ${ }^{19}$ using 6 types of solution as follows: water (Fraction 1), $1 \mathrm{M}$ magnesium chloride (Fraction 2), $1 \mathrm{M}$ sodium acetate (Fraction 3), $0.04 \mathrm{M}$ hydroxylamine hydrochloride in $25 \%$ acetic acid (Fraction 4), 0.02 $\mathrm{M}$ nitric acid, 30\% hydrogen peroxide and $3.2 \mathrm{M}$ ammonium acetate (Fraction 5), and concentrate nitric acid (Fraction 6). The determination of the amounts of the metals extracted was by AAS ${ }^{15}$.

\section{Bioavailable index (BI) ${ }^{20}$}

Data from the sequential extraction

$$
\mathrm{BI}=\frac{\mathrm{F} 1+\mathrm{F} 2+\mathrm{F} 3}{\mathrm{~F} 1+\mathrm{F} 2+\mathrm{F} 3+\mathrm{F} 4+\mathrm{F} 5+\mathrm{F} 6} \times 100,
$$

where F1 (Fraction 1) = water soluble form, F2 (Fraction 2) = exchangeable form, F3 (Fraction 3 ) $=$ bound to carbonate form, F4 (Fraction 4) = bound to Fe and Mn oxide form, F5 (Fraction 5) = bound to organic matter form, and F6 (Fraction 6) = residual form.

\section{Statistical analysis}

All experiments were performed in triplicate. The one-way analysis of variance (ANOVA) was used to determine the statistically significant (at 95\% confidence level) difference between the two or more groups of data using SPSS version 23.

\section{RESULTS AND DISCUSSION}

\section{Soil characteristics}

Table 1 showed the characteristics of two types of soil. C soil was an extremely acidic soil. It had rather
Table 2 Characteristics of clay minerals.

\begin{tabular}{|c|c|c|c|}
\hline Parameter & Zeolite (Z) & Sepiolite (S) & Diatomite (D) \\
\hline Moisture (\%) & $1.21 \pm 0.15$ & $7.27 \pm 0.15$ & $0.08 \pm 0.02$ \\
\hline $\mathrm{CEC}(\mathrm{cmol} / \mathrm{kg})$ & $11.98 \pm 0.22$ & $7.09 \pm 0.01$ & $4.72 \pm 0.01$ \\
\hline $\mathrm{SA}\left(\mathrm{m}^{2} / \mathrm{g}\right)$ & 33.51 & 169.20 & 25.71 \\
\hline $\mathrm{PV}(\mathrm{cc} / \mathrm{g})$ & 0.045 & 0.500 & 0.030 \\
\hline PS (nm) & 8.202 & 11.830 & 5.562 \\
\hline $\mathrm{SiO}_{2}(\%)$ & 60.7 & 58.2 & 88.9 \\
\hline MgO (\%) & 1.07 & 32.3 & 0.53 \\
\hline $\mathrm{Al}_{2} \mathrm{O}_{3}(\%)$ & 29.9 & - & 3.67 \\
\hline $\mathrm{Na}_{2} \mathrm{O}(\%)$ & 3.53 & - & 3.46 \\
\hline $\mathrm{CaO}(\%)$ & 3.16 & 0.39 & 0.40 \\
\hline $\mathrm{TiO}_{2}(\%)$ & 0.87 & - & 0.19 \\
\hline $\mathrm{Fe}_{2} \mathrm{O}_{3}(\%)$ & - & 0.61 & - \\
\hline Other element & $\begin{array}{l}\mathrm{Cl}, \mathrm{WO}_{3} \\
\mathrm{CuO}\end{array}$ & $\begin{array}{c}\mathrm{SO}_{3}, \mathrm{La}_{2} \mathrm{O}_{3} \\
\mathrm{Sm}_{2} \mathrm{O}_{3}, \mathrm{Ho}_{2} \mathrm{O}_{3}\end{array}$ & $\begin{array}{c}\mathrm{Gd}_{2} \mathrm{O}_{3}, \mathrm{WO}_{3}, \\
\mathrm{~Tb}_{4} \mathrm{O}_{7}\end{array}$ \\
\hline $\mathrm{Zn}(\mathrm{mg} / \mathrm{kg})$ & $64.50 \pm 4.80$ & $31.69 \pm 7.05$ & $11.12 \pm 0.96$ \\
\hline $\mathrm{Cu}(\mathrm{mg} / \mathrm{kg})$ & $9.08 \pm 0.45$ & $8.73 \pm 0.43$ & $3.25 \pm 0.40$ \\
\hline $\mathrm{Cr}(\mathrm{mg} / \mathrm{kg})$ & $13.55 \pm 0.61$ & $14.69 \pm 0.46$ & $12.60 \pm 0.43$ \\
\hline $\mathrm{Ni}(\mathrm{mg} / \mathrm{kg})$ & $19.05 \pm 2.20$ & $10.69 \pm 1.77$ & $4.57 \pm 0.11$ \\
\hline pHpzc & 2.80 & 2.60 & 3.20 \\
\hline
\end{tabular}

high organic matter (OM), high cation exchange capacity (CEC), and low fertility. The concentration of zinc, copper, chromium, and nickel is in the soil quality standards that are used for agriculture ${ }^{21}$. S soil was an extremely acidic with rather high OM, low CEC, and low fertility. The concentration of metals in S soil was lower than that in $\mathrm{C}$ soil.

\section{The characteristics of clay minerals}

Table 2 showed the characteristics of zeolite, sepiolite, and diatomite. Zeolite, sepiolite, and diatomite contain $\mathrm{Si}^{4+}$ as the main component in their structures. Clay minerals have a large number of negative charges on the surface caused by the fracture of the $\mathrm{Si}-\mathrm{O}-\mathrm{Si}$ bond and formation of the $\mathrm{SiO}-\mathrm{H}$ group. The replacement of $\mathrm{Si}^{4+}$ with $\mathrm{Al}^{3+}$ is an isomorphic substitution process within the mineral structure. It is another source of negative charges for mineral structures. The replacement of $\mathrm{Si}^{4+}$ with $\mathrm{Al}^{3+}$ will greatly affect the strength of the negative ions on the surface. As a result of the low $\mathrm{Si} / \mathrm{Al}$ ratio, zeolite has a high $\mathrm{CEC}^{22}$. Diatomite, a mineral formed by the accumulation of diatom silica shells, is high in $\mathrm{SiO}_{2}$ (88.9\%) (Table 2). The negative charge of diatomite, therefore, comes from the $\mathrm{SiO}-\mathrm{H}$ group on the surface ${ }^{23}$. Sepiolite is a magnesium silicate mineral, containing $\mathrm{SiO}_{2}$ (58.2\%) and $\mathrm{MgO}(32.3 \%)$ as the main components, with the highest surface area, porosity volume, and porosity size. The concentration of heavy metals was the lowest in diatomite and the highest in zeolite. The point of zero charges (pHpzc) of zeolite, sepiolite, and diatomite was $2.80,2.60$, and 3.20 , 
respectively. These values indicated that the charge of the zeolite, sepiolite, and diatomite surface was negative $\left(\mathrm{SiO}^{-}\right)$when adding zeolite, sepiolite, and diatomite into clay ( $\mathrm{pH} 4.41)$ and sandy clay loam (pH 4.80).

\section{Soil $\mathrm{pH}$ after adding modifiers}

After mixing the soils and clay minerals for a period of 30 and 60 days, the results of monitoring the changes in soil $\mathrm{pH}$ were shown in Table 3 . The $\mathrm{pH}$ of both types of soils increased when adding zeolite, sepiolite, and diatomite. Clay mineral helps to reduce the number of hydrogen ions $\left(\mathrm{H}^{+}\right)$present in the soil. There are two reasons for this: firstly, the negative ions on the surface of the clay minerals $\left(\mathrm{SiO}^{-}\right.$or $\left.\mathrm{AlO}^{-}\right)$can absorb the hydrogen ions $\left(\mathrm{H}^{+}\right)$ contained in the soil ${ }^{24}$; secondly, the hydrogen ions $\left(\mathrm{H}^{+}\right)$in the soil replace the elements in the structure of clay minerals such as $\mathrm{Na}^{+}, \mathrm{Mg}^{2+}$ and $\mathrm{Ca}^{2+25,26}$. The sorting of the ability to replace the cations in descending order was as follows: $\mathrm{Al}^{3+}>\mathrm{Ca}^{2+}$ $>\mathrm{Mg}^{2+}>\mathrm{Na}^{+}$. The least surface area, porosity volume, porosity size, and number of exchanged cations for diatomite compared to zeolite and sepiolite resulted in the smallest change in the soil $\mathrm{pH}$ value when modified with diatomite. For the control, sepiolite, and zeolite (7.5\%), when clay minerals were added to the soil for 30 and 60 days, the $\mathrm{pH}$ increased significantly at a $95 \%$ confidence level. For diatomite and zeolite (2.5\% and $5 \%)$, the $\mathrm{pH}$ decreased non-significantly at a $95 \%$ confidence level when adding clay minerals to the soil for 30 and 60 days. The ion exchange process can occur well within 30 days when adding sepiolite and $7.5 \%$ zeolite to the soil due to the high surface area, porosity volume, and porosity size. No difference in soil $\mathrm{pH}$ was observed when left for 30 or 60 days.

\section{Results from the sequential extraction}

After mixing clay minerals in both soils (C and S) for 60 days, the sequential extraction was carried out. In Fig. 1, Fractions 1, 2, 3, 4, 5, and 6 indicated metals in soluble form, exchangeable form, bound to carbonate form, bound to oxide form, bound to organic matter form, and residual form, respectively. The symbols $\mathrm{D}, \mathrm{S}$, and $\mathrm{Z}$ represented diatomite, sepiolite, and zeolite, respectively. After adding the clay minerals to the soil, the metals in oxide form (Fraction 4) increased.

The metals in Fractions 1, 2, and 3 showed unstable forms, while Fractions 4, 5, and 6 showed stable forms. Chromium had the best adsorption capacity and bonded with various elements in the soil, followed by copper, zinc, and nickel, respectively. All four metals are transition metals which contain a group of electrons that do not fully fill in the dorbital $\left(\mathrm{Cr}^{3+}=[\mathrm{Ar}] 3 \mathrm{~d}^{3}, \mathrm{Cu}^{2+}=[\mathrm{Ar}] 3 \mathrm{~d}^{9}, \mathrm{Zn}^{2+}=\right.$ $[\mathrm{Ar}] 3 \mathrm{~d}^{10}$, and $\left.\mathrm{Ni}^{2+}=[\mathrm{Ar}] 3 \mathrm{~d}^{8}\right)$. According to the hard-soft acids bases (HSAB) principle, the bond of a complex compound will be stable when there is a reaction between the hard acid ions and hard base ions ${ }^{27}$. The hard acid property of the chromium ion is higher than copper, zinc and nickel ions. Thus, the chromium ion better adsorbs to oxides and organic matter in the soil (hard bases) than other metals. In addition, it can be seen that the sequence of the hydrolysis reactions is consistent and correlates with the liking of absorbing heavy metals that occur in the soil when considering the hydrolysis constant $\left(\mathrm{K}_{\mathrm{h}}\right)$ of chromium $\left(10^{-3.96}\right)$, copper $\left(10^{-7.7}\right)$, zinc $\left(10^{-9.2}\right)$, and nickel $\left(10^{-9.9}\right)^{28}$. The addition of sepiolite resulted in higher amounts of the stable form of heavy metals in the soil compared to adding zeolite or diatomite (Fig. 1). This is likely because sepiolite has the highest surface area, porosity volume, and porosity size. The higher the amount of sepiolite, the higher the number of the metal in the stable form. From Fig. 1, the highest impact was on $\mathrm{Ni}$, followed by $\mathrm{Zn}, \mathrm{Cu}$, and $\mathrm{Cr}$, respectively, when adding the clay minerals to the soil.

\section{Bioavailable index (BI)}

Tables 4 and 5 showed the bioavailable index of metals in clay and sandy clay loam soil after incubation for 30 and 60 days. Chromium had the least BI value (Tables 4 and 5). It means $\mathrm{Cr}$ had the least risk or ability to move to the living things. Sepiolite successfully reduced heavy metals movement in the soil but the efficiency of diatomite to minimize the movement of heavy metals was low. When the clay minerals were left in the soil longer, the BI value decreased because heavy metals firmly stuck to the soil. Considering the control of clay when changing the incubation time from 30 days to 60 days, the $\mathrm{BI}$ value of $\mathrm{Zn}, \mathrm{Cu}, \mathrm{Cr}$, and $\mathrm{Ni}$ decreased about $15 \%$, $51 \%, 63 \%$, and $23 \%$, respectively. After adding sepiolite at the amount of $7.5 \%$ and leaving for 60 days, the $\mathrm{BI}$ value of $\mathrm{Zn}, \mathrm{Cu}, \mathrm{Cr}$, and $\mathrm{Ni}$ decreased about $48 \%, 82 \%, 74 \%$, and $71 \%$, respectively. Without adding any clay mineral, the BI value of metals in the sandy clay loam soil was higher than clay soil. Considering the control of sandy clay loam when changing the incubation time from 30 days to 60 days, the $\mathrm{BI}$ value of $\mathrm{Zn}, \mathrm{Cu}, \mathrm{Cr}$, and $\mathrm{Ni}$ decreased about $18 \%, 36 \%, 74 \%$, and $37 \%$, respectively. The decrease of BI of sandy clay loam soil was more 
Table $3 \mathrm{pH}$ of soil after mixing with clay minerals!

\begin{tabular}{|c|c|c|c|c|c|}
\hline \multirow{2}{*}{ Clay mineral } & \multirow{2}{*}{$\%$ of mixing } & \multicolumn{2}{|c|}{ Clay (C) } & \multicolumn{2}{|c|}{ Sandy clay loam (S) } \\
\hline & & 30 days & 60 days & 30 days & 60 days \\
\hline control & 0 & $4.29 \pm 0.02^{g}$ & $4.16 \pm 0.02^{g}$ & $4.62 \pm 0.03^{n}$ & $4.41 \pm 0.02^{n}$ \\
\hline \multirow[t]{3}{*}{ zeolite } & 2.5 & $4.55 \pm 0.00^{\mathrm{e}}$ & $4.26 \pm 0.03^{f}$ & $4.96 \pm 0.04^{1}$ & $4.63 \pm 0.02^{n}$ \\
\hline & 5.0 & $4.51 \pm 0.04^{\mathrm{e}}$ & $4.42 \pm 0.03^{\mathrm{d}}$ & $5.22 \pm 0.04^{\mathrm{k}}$ & $4.97 \pm 0.04^{1}$ \\
\hline & 7.5 & $4.71 \pm 0.01^{\mathrm{c}}$ & $4.61 \pm 0.03^{c}$ & $5.52 \pm 0.08^{\mathrm{j}}$ & $5.28 \pm 0.03^{\mathrm{j}}$ \\
\hline \multirow[t]{3}{*}{ sepiolite } & 2.5 & $4.67 \pm 0.05^{d}$ & $4.46 \pm 0.04^{\mathrm{d}}$ & $5.48 \pm 0.02^{\mathrm{j}}$ & $5.28 \pm 0.03^{j}$ \\
\hline & 5.0 & $4.81 \pm 0.01^{b}$ & $4.74 \pm 0.04^{b}$ & $5.74 \pm 0.03^{\mathrm{i}}$ & $5.39 \pm 0.03^{\mathrm{i}}$ \\
\hline & 7.5 & $5.04 \pm 0.02^{\mathrm{a}}$ & $5.04 \pm 0.03^{\mathrm{a}}$ & $6.07 \pm 0.03^{\mathrm{h}}$ & $5.73 \pm 0.06^{\mathrm{h}}$ \\
\hline \multirow[t]{3}{*}{ diatomite } & 2.5 & $4.36 \pm 0.02^{f}$ & $4.28 \pm 0.04^{e}$ & $4.82 \pm 0.07^{\mathrm{m}}$ & $4.65 \pm 0.01^{\mathrm{n}}$ \\
\hline & 5.0 & $4.37 \pm 0.03^{f}$ & $4.28 \pm 0.03^{\mathrm{e}}$ & $5.16 \pm 0.01^{\mathrm{k}}$ & $4.68 \pm 0.02^{n}$ \\
\hline & 7.5 & $4.37 \pm 0.02^{f}$ & $4.31 \pm 0.01^{\mathrm{e}}$ & $5.17 \pm 0.01^{\mathrm{k}}$ & $4.80 \pm 0.02^{\mathrm{m}}$ \\
\hline
\end{tabular}

$\dagger$ The letters a, b, c, d, e, f, g, h, i, j, k, l, m, and n mean the statistically significant difference $(p<0.05)$. Different letters indicate significant differences.

Table 4 Bioavailable index of metals in clay soil after incubation for 30 and 60 days!

\begin{tabular}{|c|c|c|c|c|c|c|c|c|}
\hline \multirow{2}{*}{$\begin{array}{l}\text { Clay with } \\
\text { clay mineral }\end{array}$} & \multicolumn{4}{|c|}{ Bioavailable index (30 days) } & \multicolumn{4}{|c|}{ Bioavailable index (60 days) } \\
\hline & $\mathrm{Zn}$ & $\mathrm{Cu}$ & $\mathrm{Cr}$ & $\mathrm{Ni}$ & $\mathrm{Zn}$ & $\mathrm{Cu}$ & $\mathrm{Cr}$ & $\mathrm{Ni}$ \\
\hline 1) & & $2^{\mathrm{a}}$ & $97 \pm 0.86^{\mathrm{a}}$ & & & $21.26 \pm 1.58^{\mathrm{h}}$ & $0.66^{\mathrm{h}}$ & $69.86=$ \\
\hline $\mathrm{Z}^{2}$ & & $34.33 \pm 4.80^{\mathrm{b}}$ & $11.66 \pm 1.91^{\mathrm{c}}$ & $88.61 \pm 1.33^{\mathrm{ab}}$ & $48.73 \pm 1.95^{\mathrm{i}}$ & $16.77 \pm 0.73^{\mathrm{ij}}$ & $4.80 \pm 0.28^{\mathrm{jk}}$ & $65.63 \pm 1.07^{\mathrm{i}}$ \\
\hline $\mathrm{Z} 5$ & $89^{\mathrm{bc}}$ & $33.63 \pm 2.31^{\mathrm{b}}$ & $13.57 \pm 0.79^{b c}$ & $85.91 \pm 0.51^{\mathrm{bc}}$ & $48.19 \pm 0.34^{\mathrm{i}}$ & $15.35 \pm 1.81^{\mathrm{j}}$ & $4.85 \pm 0.64^{\mathrm{jk}}$ & $62.67 \pm 0.97^{\mathrm{j}}$ \\
\hline $\mathrm{CZ} 7$ & $.53^{\mathrm{c}}$ & $29.26 \pm 1.32^{\mathrm{bc}}$ & $12.68 \pm 0.23^{c}$ & $81.55 \pm 0.70^{\mathrm{d}}$ & $43.74 \pm 2.15^{\mathrm{j}}$ & $12.52 \pm 1.33^{\mathrm{k}}$ & $4.73 \pm 0.16^{\mathrm{jk}}$ & $62.39 \pm 1.91^{\mathrm{j}}$ \\
\hline $\mathrm{CS} 2$ & $8^{\mathrm{d}}$ & $27.10 \pm 5.98^{c d}$ & $11.86 \pm 2.12^{\mathrm{c}}$ & $76.41 \pm 3.68^{\mathrm{e}}$ & $39.33 \pm 3.24^{\mathrm{k}}$ & $12.19 \pm 0.35^{\mathrm{k}}$ & $4.80 \pm 0.12^{\mathrm{jk}}$ & $54.12 \pm 1.09^{\mathrm{k}}$ \\
\hline$S$ & & $24.85 \pm 3.68^{\mathrm{de}}$ & $12.24 \pm 1.24^{\mathrm{c}}$ & $56.62 \pm 3.62^{f}$ & $32.89 \pm 1.00^{1}$ & $9.44 \pm 0.56^{1}$ & $4.73 \pm 0.26^{\mathrm{jk}}$ & $37.04 \pm 0.61^{1}$ \\
\hline$S$ & & $22.22 \pm 1.61^{\mathrm{e}}$ & $12.97 \pm 1.12^{\mathrm{bc}}$ & $40.44 \pm 2.06^{g}$ & $33.02 \pm 2.40^{1}$ & $8.01 \pm 0.76^{1}$ & $4.46 \pm$ & $0.68^{\mathrm{m}}$ \\
\hline D & $67^{\mathrm{b}}$ & $34.94 \pm 3.48^{b}$ & $14.88 \pm 0.70^{\mathrm{b}}$ & $84.69 \pm 0.46^{\mathrm{cd}}$ & $47.56 \pm 1.53^{\mathrm{i}}$ & $17.50 \pm 0.80^{\mathrm{i}}$ & $5.44 \pm 0.38^{i j}$ & $66.62 \pm 0.38^{\mathrm{i}}$ \\
\hline CD 5 & $1^{\text {bc }}$ & $34.40 \pm 4.8$ & $13.16 \pm 0.38^{b c}$ & $84.05 \pm 0.38$ & $49.76 \pm 1.92^{\mathrm{i}}$ & $18.01 \pm 0.56^{i}$ & $5.22 \pm 0.51^{\mathrm{ij}}$ & $66.95 \pm 2.53^{\mathrm{i}}$ \\
\hline CD $7.5 \%$ & $.65 \pm 4.55^{\mathrm{bc}}$ & $31.64 \pm 0.99^{b c}$ & $11.94 \pm 0.45^{c}$ & $83.99 \pm 1.15$ & $49.35 \pm 3.03^{i}$ & $17.25 \pm 0.80^{\mathrm{i}}$ & $5.59 \pm 0.31^{\mathrm{i}}$ & $65.68 \pm 0.42^{\mathrm{i}}$ \\
\hline
\end{tabular}

$\dagger$ The letters $a, b, c, d, e, f, g, h, i, j, k, 1$, and m mean the statistically significant difference $(p<0.05)$. Different letters indicate significant differences.

than that of clay soil. After adding sepiolite $7.5 \%$ and leaving for 60 days, the $\mathrm{BI}$ value of $\mathrm{Zn}, \mathrm{Cu}, \mathrm{Cr}$, and $\mathrm{Ni}$ decreased about 52\%, 82\%, 75\%, and 84\%, respectively.

\section{CONCLUSIONS}

Clay soil (C) from Mon Thong sub-district, Bang Nam Priao district and sandy clay loam soil samples (S) from Plaeng Yao sub-district, Plaeng Yao district were extremely acidic, with rather high OM. Nickel was transferred into plants and organisms

Table 5 Bioavailable index of metals in sandy clay loam soil after incubation for 30 and 60 days!

\begin{tabular}{|c|c|c|c|c|c|c|c|c|}
\hline \multirow{2}{*}{$\begin{array}{l}\text { Sandy clay } \\
\text { loam with } \\
\text { clay mineral }\end{array}$} & \multicolumn{4}{|c|}{ Bioavailable index (30 days) } & \multicolumn{4}{|c|}{ Bioavailable index (60 days) } \\
\hline & $\mathrm{Zn}$ & $\mathrm{Cu}$ & $\mathrm{Cr}$ & $\mathrm{Ni}$ & $\mathrm{Zn}$ & $\mathrm{Cu}$ & $\mathrm{Cr}$ & $\mathrm{Ni}$ \\
\hline S (control) & $4.00^{\mathrm{a}}$ & & $1.51^{\mathrm{a}}$ & $1.39^{\mathrm{a}}$ & $5.70 \pm 1.44_{. .}^{\mathrm{h}}$ & $31.94 \pm 2.61^{\mathrm{h}}$ & $34^{\mathrm{h}}$. & \\
\hline & & $10^{\mathrm{b}}$ & $20.08 \pm$ & & $64^{\mathrm{ij}}$ & & & \\
\hline & & $34.80 \pm 3.63^{c}$ & $19.34 \pm 3.69^{b}$ & $.63 \pm 10.78^{b c}$ & $45.22 \pm 1.07^{j}$ & $23.95 \pm 1.72^{j}$ & $6.88 \pm 0.14^{\mathrm{h}}$ & $41.16 \pm 1.20^{\mathrm{k}}$ \\
\hline & $30^{f}$ & $29.29 \pm 1.37^{\mathrm{cd}}$ & $16.47 \pm 1.51^{b}$ & $51.24 \pm 8.79^{\mathrm{de}}$ & $38.82 \pm 0.01^{\mathrm{k}}$ & $16.26 \pm 2.01^{\mathrm{k}}$ & $6.39 \pm 0.19^{h i}$ & $29.25 \pm 1.10^{\mathrm{m}}$ \\
\hline & & $27.52 \pm$ & $17.89 \pm 0.9$ & $60.28 \pm 6.26^{\mathrm{cd}}$ & $40.38 \pm 5.04^{k}$ & $15.82 \pm 1.25^{\mathrm{k}}$ & $6.09 \pm 0.07^{i}$ & $32.44 \pm 1.47^{1}$ \\
\hline & $83^{f}$ & $27.38 \pm$ & $17.36 \pm 1.2$ & $42.04 \pm 10.23^{\mathrm{de}}$ & $37.56 \pm 3.10^{\mathrm{k}}$ & $11.71 \pm 0.59^{1}$ & $7.08 \pm 0.94^{h}$ & $17.45 \pm 0.39^{n}$ \\
\hline 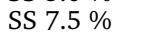 & $36.57 \pm$ & $24.17 \pm 1.65^{\mathrm{e}}$ & $15.54 \pm 2$ & $25.85 \pm 6.04^{f}$ & $32.71 \pm 5.50^{1}$ & $8.84 \pm 1.82^{1}$ & $6.74 \pm 0.10^{h i}$ & $14.30 \pm 2.63^{h}$ \\
\hline & $.97 \pm 5$ & $37.39 \pm 2.86^{\mathrm{bc}}$ & $16.62 \pm$ & $81.15 \pm 1.49^{b}$ & $54.67 \pm 1.71^{h}$ & $28.58 \pm 2.95^{\mathrm{hi}}$ & $6.89 \pm 0.51^{h}$ & $53.13 \pm 1.69^{h}$ \\
\hline & $62.81 \pm 4.86^{\mathrm{b}}$ & $40.04 \pm 3.25^{\mathrm{b}}$ & $16.91 \pm 3.40^{\mathrm{b}}$ & $85.55 \pm 3.14^{\mathrm{ab}}$ & $53.23 \pm 0.86^{\mathrm{i}}$ & $26.09 \pm 3.43^{\mathrm{ij}}$ & $6.81 \pm 0.26^{h i}$ & $52.07 \pm 1.51^{\mathrm{i}}$ \\
\hline D $7.5 \%$ & $54.50 \pm 5.06^{d}$ & $36.17 \pm 3.19^{\mathrm{bc}}$ & ${ }^{c} 17.39 \pm 1.59^{b}$ & $79.49 \pm 1.64^{b}$ & $52.46 \pm 1.30^{\mathrm{i}}$ & $24.85 \pm 2.31^{\mathrm{j}}$ & $6.38 \pm 0.02^{h i}$ & $50.56 \pm 0.90^{\mathrm{i}}$ \\
\hline
\end{tabular}

$\dagger$ The letters a, b, c, d, e, f, g, h, i, j, k, l, m, and n mean the statistically significant difference $(p<0.05)$. Different letters indicate significant differences. 


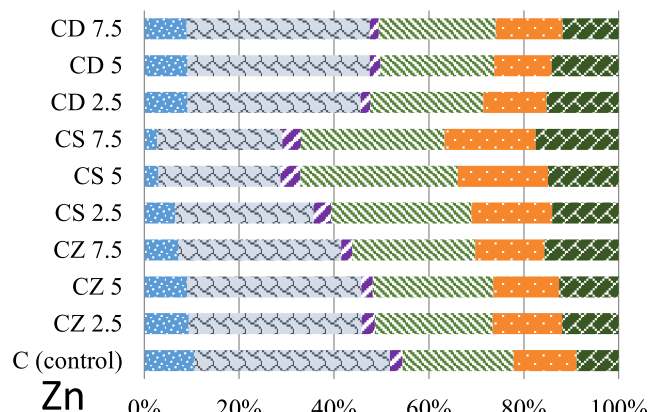

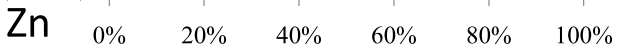

CD 7.5 หลЋ

CD $515007 \times$ स:

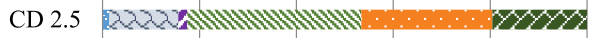

CS 7.5 М

CS 5 DN

CS 2.5 RAR N W N

CZ7.5 $\operatorname{xan} \ldots \ldots$

CZ 51000 N.

CZ2.5 LAX W

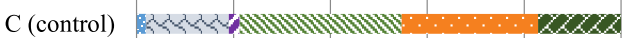

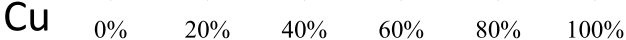

CD 7.5 A.

CD 5 Mm:

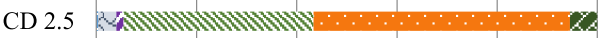

CS 7.5 N

CS 5 M

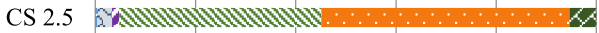

CZ7.5 $20 . \cdots \cdots$

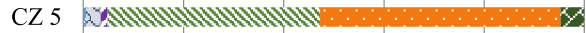

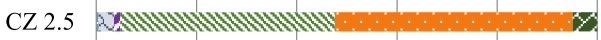

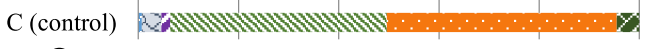

$\begin{array}{lllllll}\mathrm{Cr} & 0 \% & 20 \% & 40 \% & 60 \% & 80 \% & 100 \%\end{array}$

CD 7.5 m w 80

CD $5 \quad 7200000000000000$ Now: $/ 8$

CD 2.5 .

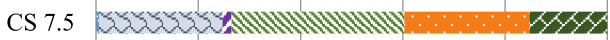

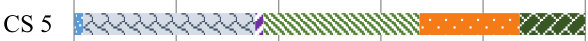

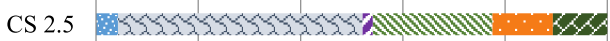

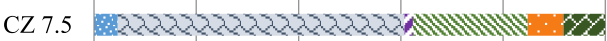

CZ 5 Frank 02

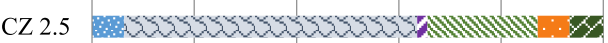

$\mathrm{C}$ (control) $\mathrm{W} \times \mathrm{N} \times \mathrm{N}$

$\mathrm{Ni} \quad 0 \% \quad 20 \% \quad 40 \% \quad 60 \% \quad 80 \% \quad 100 \%$

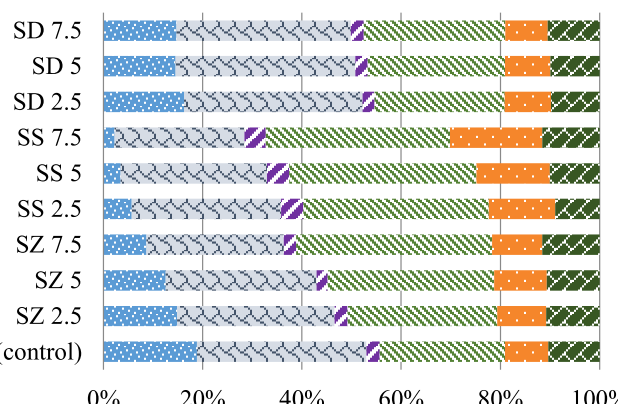

$\begin{array}{llllll}0 \% & 20 \% & 40 \% & 60 \% & 80 \% & 100 \%\end{array}$

SD 7.5 mo $2000 \%$

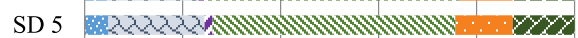

SD 2.5 man 282

SS 7.5 DSRL_.

SS 5 DONA

SS 2.5 REQ

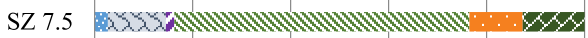

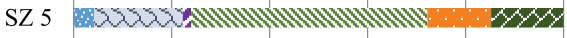

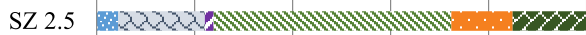
$\mathrm{S}$ (control)
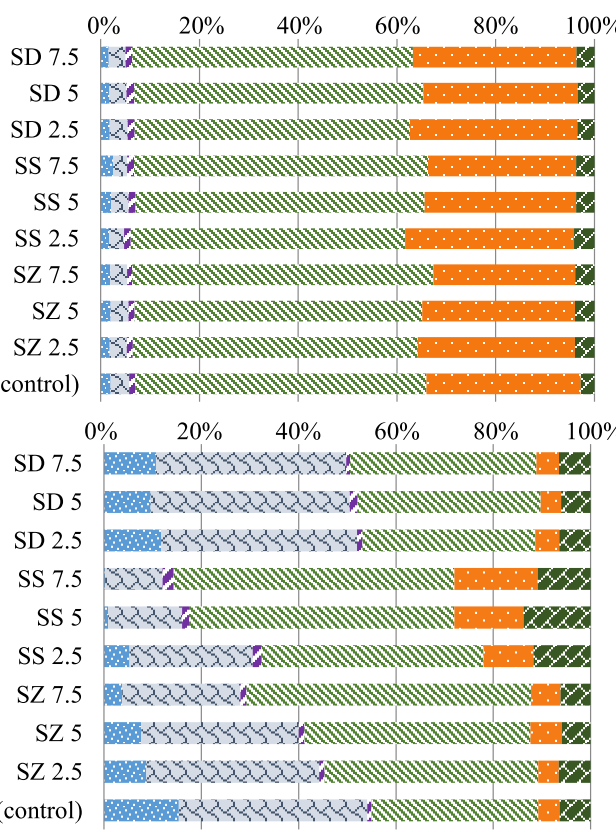

Fraction $1 \quad$ Fraction $2 \quad \square$ Fraction 3

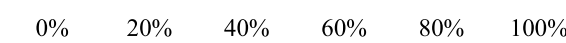

Fig. 1 Forms of heavy metals in soils mixed with clay minerals for 60 days.

at the highest risk followed by zinc, copper, and chromium. For zeolite, sepiolite, and diatomite, the specific surface area was $33.51,169.20$, and 25.71 $\mathrm{m}^{2} / \mathrm{g}$, the surface charge was $-20.79,-23.41$, and $-19.77 \mathrm{mV}$, while the pHpzc was $2.80,2.60$, and 3.20 , respectively. Sepiolite has the highest surface area, porosity volume, porosity size, and surface charge but lowest in the pHpzc value thus sepiolite at the amount of $7.5 \%$ was the best to reduce the risk or ability of heavy metals to move to the living things. The longer the incubation day, the lower the BI value of heavy metals. This study confirmed that adding of sepiolite can successfully reduce the risk of heavy metals to be transferred from soil to biosystem.

Acknowledgements: Authors would like to express gratitude to the Division of Science, King Mongkut's Institute of Technology Ladkrabang for supporting the 
financial and providing equipments and chemicals.

\section{REFERENCES}

1. Sun Y, Zhou Q, Xie X, Liu R (2010) Spatial, sources and risk assessment of heavy metal contamination of urban soils in typical regions of Shenyang, China. $J$ Hazard Mater 174, 455-462.

2. ATSDR (2017) ATSDR's Substance Priority List, available at: www.atsdr.cdc.gov/spl.

3. Mulligan CN, Yong RN, Gibbs BF (2001) emediation technologies for metal-contaminated soils and groundwater: an evaluation. Eng Geol 60, 193-207.

4. Huang G, Su X, Rizwan MS, Zhu Y, Hu H (2016) Chemical immobilization of $\mathrm{Pb}, \mathrm{Cu}$, and $\mathrm{Cd}$ by phosphate materials and calcium carbonate in contaminated soils. Environ Sci Pollut Res 23, 16845-16856.

5. Irshad M, Khan RU, Jadoon S, Hassan A, Eneji AE (2014) Effect of phosphate rock on the solubility of heavy metals in soils saturated with industrial wastewater. Can J Soil Sci 94, 543-549.

6. Ma QY, Traina SJ, Logan TJ, Ryan JA (1993) In situ lead immobilization by apatite. Environ Sci Technol 27, 1803-1810.

7. Sun Y, Li Y, Xu Y, Liang X, Wang L (2015) In situ stabilization remediation of cadmium and lead cocontaminated paddy soil using bentonite. Appl Clay Sci 105-106, 200-206.

8. Liang X, Han J, Xu Y, Sun Y, Wang L, Tan X (2014) In situ field-scale remediation of Cd polluted paddy soil using sepiolite and palygorskite. Geoderma 235-236, 9-18.

9. Li H, Shi WY, Shao H, Shao M (2009) The remediation of the read-polluted garden soil by natural zeolite. J Hazard Mater 169, 1106-1111.

10. Ye X, Kang S, Wamg H, Li H, Zhang Y (2015) Modified natural diatomite and its enhanced immobilization of lead, copper and cadmium in simulated soils. J Hazard Mater 289, 210-218.

11. Zhang G, Lin Y, Wang M (2011) Remadiation of copper polluted red soils with clay materials. $J$ Environ Sci 23, 461-467.

12. Zhang M, Pu J (2011) Mineral materials as feasible amendments to stabilize heavy metals in polluted urban soils. J Environ Sci 23, 607-615.

13. Venegas A, Rigol A, Vidal M (2015) Viability of organic wastes and biochars as amendments for the remediation of heavy metal-contaminated soils. Chemosphere 119, 190-198.

14. Department of Land Development (2014) Manual of Soil Analysis, Soil Fertility, Soil Improvement Materials and Analysis to Certify the Product, Ministry of Agriculture and Cooperatives, Thailand.

15. US EPA (1996) Acid Digestion of Sediments, Sludges and Soil / SW-846 Method 3050b, available at: www.epa.gov/sites/production/files/2015-06/ documents/epa-3050b.pdf.

16. Anderson MA, Rubin AJ (1981) Adsorption of Inorganic at Solid-Liquid Interfaces, Ann Arbor Science, Ann Arbor, Mich.

17. Tan WF, Lu SJ, Liu F, Feng XH, He JZ (2008) Determination of the point of zero charge of manganese oxides with different methods including an improved salt titration method. Soil Sci 173, 277-286.

18. Mahmood T, Saddique MT, Naeem A, Westerhoff $\mathrm{P}$, Mustafa S, Alum A (2011) Comparison of different methods for the point of zero charge determination of NiO. Ind Eng Chem Res 50, 10017-10023.

19. Tessier A, Campbell PG, Bisson M (1979) Sequential extraction procedure for the speciation of particulate trace metals. Anal Chem 51, 844-851.

20. Kabala C, Singh BR (2001) Fractionation and mobility of copper, lead and zinc in soil profiles in vicinity of a copper smelter. J Environ Qual 30, 485-492.

21. Pollution Control Department: Soil Quality Standards, available at: www.pcd.go.th/info_serv/reg std_soil01.html. [in Thai]

22. Barczyk K, Mozga W, Krol M (2014) Studies of anions sorption on natural zeolites. Spectrochim Acta A 133, 876-882.

23. Caliskan N, Alkan S, Sogut EG, Alacabey I (2011) Adsorption of Zinc(II) on diatomite and manganeseoxide-modified diatomite: A kinetic and equilibrium study. J Hazard Mater 193, 27-36.

24. Tahervand A, Jalali M (2017) Sorption and desorption of potentially toxic metals ( $\mathrm{Cd}, \mathrm{Cu}, \mathrm{Ni}$ and $\mathrm{Zn}$ ) by soil amended with bentonite, calcite and zeolite as a function of pH. $J$ Geochem Explor 181, 148-159.

25. Sprynskyy M (2009) Solid-liquid-solid extraction of heavy metals ( $\mathrm{Cr}, \mathrm{Cu}, \mathrm{Cd}, \mathrm{Ni}$ and $\mathrm{Pb}$ ) in aqueous systems of zeolite-sewage sludge. $J$ Hazard Mater 161, 1377-1383.

26. Sabah E, Ouki S (2017) Sepiolite and sepiolitebound acid interactions in alkaline media and the mechanism of the formation of sepiolite-humic acid complexes. Int J Miner Process 162, 69-80.

27. Pearson RG (1963) Hard and Soft Acid and Bases. $J$ Am Chem Soc 85, 3533-3539.

28. Pohlmeier A (2004) Metal speciation, chelation and complexing ligands in plants. In: Prasad MNV (ed) Heavy Metal Stress in Plants, Springer, Berlin, Heidelberg, pp 28-46. 